\title{
Security in Niamey: an anthropological perspective on policing and an act of terrorism in Niger*
}

\author{
MirCo GÖPFERT \\ Department of Anthropology and African Studies, Johannes Gutenberg \\ University Mainz, Forum Universitatis 6, 55099 Mainz, Germany
}

Email: mirco.goepfert@uni-mainz.de

\section{A B S T R A C T}

The abduction of two Frenchmen in January 2011 in Niamey's supposedly most secure neighbourhood has led many to question the functioning of the city's security apparatus. This paper analyses Niamey's security landscape, initially from an historical and then from a spatial perspective. It argues that for a comprehensive analysis of security, we must first decentre our perspective on security construction, and thus take informal non-organised modes of policing just as seriously as policing by state and vigilante organisations; and second, take into account the inseparability of sociality and security, a fragile balance of trust and acceptable risk. In conclusion I argue that this focus may be one way of comprehending the kidnapping: how was it possible and what were its implications for Niamey's security landscape?

* Previous drafts of this paper were presented at the Centre de Recherches Sociologiques sur le Droit et les Institutions Pénales (CESDIP) in Guyancourt, France, in April 2009, and in the panel 'Spaces of (In)Security' during the European Conference on African Studies, Leipzig, in June 2oog. The fieldwork it is based on was made possible by the financial support of the Volkswagen Foundation, the Sulzmann Foundation, the German National Academic Foundation, as well as by the support offered at the Laboratoire d'Études et de Recherches Sociologiques sur les Dynamiques Sociales et le Développement Local (LASDEL), Niamey. For constructive comments on earlier versions of this text, many thanks go to Carola Lentz, Thomas Bierschenk, Mahaman Tidjani-Alou, Jan Beek, Jan Budniok, Julia Dieckmann, Julia Eckert, Fabien Jobard, Thomas Kirsch, Julie Poppe, Chris Willott and three anonymous referees. 
On 7 January 2011 at about 11 p.m., two Frenchmen were abducted from a restaurant in central Niamey. A group of heavily armed men, arriving in white four-wheel-drive vehicles, entered the restaurant, picked out the two young men sitting near the entrance, and forced them into one of their cars. A few days after a failed rescue attempt by French Special Forces, al-Qaeda in the Islamic Maghreb (AQIM) claimed responsibility for the abduction. 'A group of mujahideen carried out on Friday, January 7 , a brave operation in the heart of the Niger capital Niamey, where they broke into the secured diplomatic neighbourhood and succeeded in kidnapping two Frenchmen', the group said in a sound recording emailed to Reuters news agency (Reuters 13.1.2011). One Frenchman was executed by the kidnappers; one died in the French attack.

This tragic occurrence has caused many to question the basic functioning of Niamey's security apparatus. How was it possible for such an incident to take place in the supposedly most secure neighbourhood? This paper develops a comprehensive analysis of Niamey's security landscape.

Most discussions of security focus on its delivery (or non-delivery) by state organisations. 'Yet the provision of security has never been a state monopoly; there has always been a pluralised field of delivery' (Hills 2009: 19; see also Olivier de Sardan 2011 ). Through a detailed analysis of this pluralised field in Niamey, I propose an anthropological complement to the analytical scheme for the study of policing in Africa presented by Hills (1996), a scholar of conflict and security governance in fragile states, and move beyond a state-centred perspective. Policing is more than what the (state) police do, Baker (2002: 30) reminds us. Rather, it is about 'regulating society and maintaining order, preventing crime, responding to crime and restoring order, and the use if necessary of instruments of coercion to assist in any of those roles' (ibid.: 29). I therefore adopt a broad perspective on what Jensen (2007: 65 ) termed 'everyday policing', and take equally seriously both state and non-state policing actors, as well as non-organised groups of youth engaged in the production of order in Niamey.

After a historical overview of the development of Niamey's security landscape since the late $1980 \mathrm{os}$, I adopt a spatio-insitutional perspective: what institutions and groups of actors are involved in the policing of different parts of Niamey? This description enables us to map ideal-type spaces of security. The following section presents a perspective on 
security that goes beyond the classical state-centred focus and puts emphasis on the intrinsic link between security and sociality, which is also essential for individuals navigating their way through Niamey. In conclusion, I build on my reflections to get a grasp of the 'act of terrorism' referred to at the beginning.

The present article should not be read as part of an anthropology of terrorism; it does not seek to be 'a new scholarly attempt to penetrate the dark mysteries of "savage political evil", (Zulaika \& Douglass 1996: $15^{\circ}$ ). It is rather an anthropological attempt to analyse the landscape in which a specific act of terrorism has taken place and what the terroristic essence of this act might be. ${ }^{1}$

\section{SECURITY I N H I T ORICAL PERSPECTIVE}

Since the late 1980 s, Niger has experienced significant political changes, beginning with the crumbling of the military-controlled oneparty system and the downfall of President Seyni Kountché. Under the pressure of structural adjustment programmes, Kountché's successor, Ali Saïbou, paved the way for democratisation and cut down on social services, student bursaries, and spending on equipment for public services, in order to balance the national budget (Gazibo 2005: 75; Gervais 1995: 33; Graybeal \& Picard 1991: 298). Civil servants, teachers, students and trades unions, who had been particularly affected by these cuts, organised and dominated proceedings at the National Conference held in 1991, the key moment in the country's democratisation. They managed to mobilise and maintain opposition to negotiations with the International Monetary Fund until 1994, so that Niger was more or less cut off from external financial flows (Gazibo 2005: 79; Gervais 1995: 37-9). In addition, it suffered from high inflation and from the fall in demand for uranium, the country's main raw material export, particularly after Chernobyl and the end of the Cold War (Gazibo 2005: 82; Gervais 1995: 40; Graybeal \& Picard 1991: 294).

This was the context in which a number of changes in the security setting took place. Most importantly, the disintegration of Kountché's military regime, hand in hand with internal financial bankruptcy, made Ali Saïbou, who was obliged to balance the national budget, cut down on police and military expenses. As a result, Kountché's powerful secret police (La Coordination) was suppressed, police patrols and raids that had previously evacuated homeless labourers and beggars from the cities to their home villages were largely trimmed back, as were road blocks throughout the country (Gilliard \& Pédenon 1996: 53; Idrissa 
2008: 177). In addition, after long years of military rule, the absence of pluralist expression and the citizens' diffuse fear vis-à-vis 'un État extrêmement policier [an extremely policed state]' (Idrissa 2008: 199), the police were largely discredited and kept a low profile, especially following the National Conference in 1991 (Lund 2001: 859-6o). Whether due to institutional changes, budgetary cut-backs, or the lowprofile of police, the period of democratic transition resulted in the retreat of the police state. One consequence was an apparent rise in petty crime, especially in the rapidly growing urban centres such as Niamey, Zinder and Maradi (see Motcho 2004). ${ }^{2}$

The decreasing intensity of the police state and the rise in crime led to the emergence of several new actors, groups and institutions active in the security setting. The first newcomer was a private security enterprise, GED Services (Gardiennage, Entretien, Désinsectisation), founded in 1988, which was followed by many more. Today more than forty security enterprises exist in Niger, the great majority active in Niamey. GED Services was founded by an ex-police officer, employing mostly ex-police and ex-military personnel. Currently, the organisation employs 2,000 security agents, 1,600 in Niamey alone (Issifi Alzouma 2008 int.; Tahirou Issaka 2008 int.). Security agents are uniformed and equipped with truncheons, pepper spray, boots, knives and walkie-talkies, depending on the client's demands and willingness to pay. Security companies are primarily contracted by NGOs or private enterprises, and only seldom by private households, who usually employ non-contracted watchmen. In order to operate they need licences issued by several ministries (Commerce; Civil Service and Labour; Interior), and to ensure that the police check the criminal records of all potential security agents; their bosses remain in close contact with old acquaintances in the state security apparatus, which helps them, amongst others, to obtain these licences (Boubacar Gandah 2008 int.). They often contract state security personnel outside Niamey to work for them as regional supervisors of the firm's security agents (Gendarme A 2009 int.).

The second group of actors entering the scene are the yan banga, who were first formed in the $195^{\circ}$ in northern Nigeria as organised political party supporters or thugs who protected their politician from the thugs of the rival party, and terrorised the opponent and his supporters (Casey 2007: 110 ; Last 2008: 55). This is where they got their name, yan banga being a Hausa adoption of the English word 'vanguards' (Ya'u 2000: 170 ). In the 1990s, the yan banga were reinvented in Niger, particularly Nigérien Hausaland close to the Nigerian border. The rise in petty crime after the National Conference of 1991 led taxi and lorry owners 
and other businessmen in Maradi and Zinder to take security into their own hands. They invited some yan banga leaders from northern Nigeria to help them form a local police force. Neither the departmental préfet (prefect) nor the police commissioner gave them written authorisation, though the police commissioner furnished them with torch lights and handcuffs, and merchants provided them with uniforms. These yan banga were mainly young unemployed men, paid with contributions from merchants in the market places and inhabitants of the housing areas they patrolled. They would beat up, humiliate and sometimes kill alleged thieves, which would be ignored by the police (Lund 2001: 859-62; Tidjani Alou 2001: 121). At least in the beginning, the population was largely satisfied with the efficiency of the yan banga. A Zinderois told me that before the arrival of the yan banga there were so many thieves and gangs, people hardly dared sending a child to the market to buy groceries. Usually he would come home without the groceries, without the money, and often with bruises. 'Mais les yan banga, ils ont mis de l'ordre [But the yan banga instilled order]' (Gendarme B 2010 int.). In Niamey, the installation of yan banga groups took off in a different manner. They were either created by the chefs de quartier (neighbourhood chiefs) or by a group of initially unorganised young, mostly unemployed men.

The third newcomer on the security scene of Niamey is a movement publicly known as fada. Fada is a Hausa word originally designating a chief's council chamber. Today, the term is applied to any gathering of young men on the street, usually preparing tea, sometimes rice with beans, listening to music and chatting until late at night. Under Kountché's military regime, which was characterised by strict military police patrols in nocturnal Niamey, it was, according to my interlocutors, virtually impossible to sit and chat on the street at night in front of one's house or compound. The place where the youth were to gather was provided by the regime itself. From the late 1970s onwards, Kountché created a tightly woven net of youth centres in the whole of the country, the so-called Samariya. ${ }^{3}$ In the aftermath of developments in the late 1980 and the early 1990 noted above, the de facto curfew after 11 p.m. was lifted and the youth centres were no longer maintained (Olivier de Sardan 2011:41). Moreover, since the economic crisis led to a gradual reduction of jobs in the civil service and difficulties in the private sector, combined with the rapid increase in the urban population, there was and still is a huge number of unemployed youth who, as a Nigérien friend of mine put it, 'don't have to get up in the morning'. ${ }^{4}$ To summarise: today, the streets of nocturnal Niamey are dominated by 
groups of young men, chatting and preparing tea, in the whole city until about midnight, and in the old neighbourhoods all night long. ${ }^{5}$ In the oldest, more popular, neighbourhoods in the centre of Niamey, the density of the fada is at its highest and they play an important role in the maintenance of order in their neighbourhood.

In the aftermath of $9 / 11$, the overall state security establishment in Niger changed significantly. Niger was counted among the 'frontline states' in the global war on terrorism (GWOT), together with Chad, Mali and Mauritania (Davis 2007: 1), because they were said to have 'what it takes to become a terrorist breeding ground' (Palmer 2007: 103). ${ }^{6}$ From 2002 onwards, Nigérien military and paramilitary forces were targeted by foreign initiatives such as the American-led Pan-Sahel Initiative, which in 2005 turned into the Trans-Sahara Counterterrorism Partnership, mounting joint military operations under US command, financial aid and training from US Special Forces (Ellis 2004: 459). ${ }^{7}$ The result in Niger was an increased militarisation with a remarkable rise in military (from 4,000 to 10,000 ) and paramilitary (from 2,000 to 4,00o) personnel until 2006 (Keenan 2006b: 281); the rise still continues with annual recruitments of army soldiers, national guards (until 2010: Forces Nationales d'Intervention et de Sécurité, FNIS), gendarmes and police of about 1,00o elements each. Since 2009, France has taken over the leading security role in the region, particularly in Niger where they aim to secure their country's economic interests in the form of the uranium exploitation in the north of the country, as French diplomats told me (see also Keenan 2009a: 17); when I talked to them in 2009 and 2010 , they also seemed to have taken over the GWOT rhetoric, terming the Sahara a 'second Afghanistan'. Nigérien authorities too adopted this anti-terrorism rhetoric, as Keenan (2007: 46-7) argues, in order to advance national interests such as strengthening their security establishments (see also Bayart 2010a: 4). Most efforts focus on the training and equipment of military and paramilitary units, and the patrolling of Niamey's streets has also significantly intensified.

MAPPING SECURITY: COLLECTIVE MODES OF PRODUCING

ORDER I N N A M EY

In this section, I adopt a broad perspective that permits an overview of the security landscape of Niamey. I distinguish four different ideal-type spaces: mythical spaces of evil or disorder; supposedly well-secured neighbourhoods policed by state security forces and private security

\section{CAMBRIDGE}

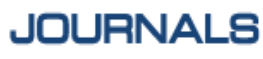


companies; spaces where yan banga act as the main security providers; and spaces policed by fada, non-organised groups of young men. ${ }^{8}$

\section{Mythical places of evil: Niamey's green space and market areas}

First, there are places not to go to, often described as anarchical territories serving as a haven for all sorts of criminals. They are mainly associated with Niamey's markets and the areas around them, and particularly with the city's green belt, other green spaces in the city, and the riverside where there are informal waste dumps, spontaneous settlements (Sahel Dimanche 16.1.2009), child prostitution (Le Flic 28.9.2010), drug addicts and dealers (tamtaminfo 29.7.2006) and other criminals. The description of these spaces as formless and chaotic is very similar to European diplomats' and media's description of desert areas also serving as a haven for all sorts of undesirables-including arms, drug and human traffickers as well as terrorists.

There are striking similarities with Shapland and Vagg's (1988: 121-2) thoughts on the common fear of public spaces, particularly parks, in a small British town. The fear of crime in these areas, they state, is rarely rooted in or tied to personal experience or actual happenings; it transcends its original cause. The park had become, just like the green space and market areas in nocturnal Niamey, or the Sahara desert, 'a place not to go to, a place populated by monsters' (ibid.: 122).

Whereas in discourse market areas and green spaces are treated with little difference, on pragmatic grounds they are not the same. Fourchard (2006: 102-3, 108) argues that crime does not generally emanate from poor neighbourhoods where mostly migrants from rural areas settle, but rather from highly frequented public spaces such as markets, bus terminals and arterial roads. ${ }^{9}$ Designating a neighbourhood as a dangerous no-go area can thus reflect both local resentments against its inhabitants (i.e. migrants) and the actual danger of crime (ibid.: 103).

\section{Well-secured territories: the Plateau}

Second, there are supposedly well-secured territories. These are basically limited to neighbourhoods in and close to the city centre, whose composition is characterised by government and diplomatic facilities, NGO headquarters, private enterprises and high-standard housing. This ideal type is represented by the Plateau, the neighbourhood in which the abduction of the two Frenchmen took place. The wealth of its dwellers and the potential appeal to burglars is 
reflected in the visible security set-up of the neighbourhood. Inhabitants transform their houses into 'bunkers' (Motcho 2004: 200), fixing iron bars in front of their windows, surrounding their property with walls up to five metres high, topped by spikes or broken glass, often overgrown by thorny climbing plants. Additionally, the landlord hires private watchmen or signs a contract with a private security enterprise. In the daytime, there are security agents on every doorstep and at night, usually after 11 p.m., numerous officious police patrol the streets of these neighbourhoods.

The main task of private security personnel is to guard a particular object. During the day the guards are often additionally assigned petty jobs for extra cash by their clients: they wash cars, water plants, or sweep the pavement or the courtyard. After office hours they sit on benches in front of the object they are supposed to be guarding, preparing tea, eating, listening to music, chatting. After 11 p.m., most of them move to the inner courtyard of their client's house where they spend the night dozing near the front door. Their job consists of 'being present and looking out', as most watchmen I talked to put it (Mohamed 2008 int.; Sarah 2008 int.). Looking out is at the core of what Shapland and Vagg (1988) term 'policing by the public'. It is a form of social control that 'has to start with someone seeing something, classifying it as problematic in some way, and noting that something must be done about it' (ibid.: 66).

Since the coup d'état staged by the military in February 2010, police patrols on the streets of Niamey have been markedly reinforced. Niamey is divided into three sectors, each patrolled by one state police organisation: one sector is patrolled by the Police Nationale, another by the Gendarmerie Nationale, and the third by the Garde Nationale. ${ }^{10}$ However, for my informants, this did not make much of a difference; for them, these different night patrols were just 'police'. ${ }^{11}$ Police patrols usually start at about 11 p.m. Earlier in the evening, the streets in these quarters are crowded: people are shopping, shopkeepers still busy, young people gathering in front of TV sets to watch soap operas and video clips, and night watchmen still sitting outside the walls of their object to guard. Around 11 p.m., most people clear the streets and return to their homes, whilst the watchmen move to the inner courtyard of their client's domicile.

The patrolling police units usually consist of about ten men mounted on a vehicle with which they patrol larger avenues. They mostly wear black battle dress and are armed with assault rifles. Every now and then they park their vehicle, stop passing cars and motorcycles, or split into 
groups in order to patrol the narrower streets of residential areas on foot. Every person found in the streets will be asked to produce their papers (identity card, birth certificate). Those unable to produce them will be taken to the police station for identification. In practice, this means the person picked up will have to spend the night at the police station, unless he or she brings a 'currency' (Bierschenk 2008: 130) such as money, social capital or even violence to their negotiations with the police.

\section{Vigilante policed areas in the periphery}

Third, there are neighbourhoods which are policed by yan banga vigilante groups. ${ }^{12}$ They are currently active only in the peripheral quarters of Niamey, characterised by relatively low population density and low-standard housing (Motcho 2004: 201). In these quarters the police conduct night patrols, if at all, merely on arterial roads.

The chef de quartier of Poudrière, a pericentral quarter of Niamey characterised by mid- and high-standard housing, told me about his yan banga (Chef de quartier Poudrière 2008 int.): when he became chief in 1992, Poudrière was still in the periphery of Niamey. In the context of rising criminality and declining police activity, he tried to take security into his own hands, but not without the police being aware. He informed the préfet of the municipality of Niamey (Communauté urbaine de Niamey), his direct superior, and called on his citizens to make their sons present themselves to him with their birth certificates. He vetted them and selected about a hundred, whose criminal records were checked by the police. In the end, he had seventy-five young men who were furnished with cartes professionnelles by the police. The chef de quartier split them into five groups, each patrolling one sector of his quarter. The police, well aware and supportive of his plans, assigned two policemen to accompany and head each of the yan banga groups on their nightly patrols. However, after a while, the police deemed it unnecessary to continue supporting the yan banga to such an extent, and withdrew from active involvement. Eventually, the yan banga turned out to be just as threatening to the community they were meant to protect as the villains they were supposed to catch (Motcho 2004: 205-6). Residents realised that the yan banga did not effectively prevent thieves from entering the neighbourhood; quite the contrary, they were seen as cooperating with thieves (e.g. taking money from them for not arresting them) or turning into thieves themselves (Boubacar Souleyman 2009 int.; Chef de quartier Lacouroussou 2008 int.; Gendarme B 2010 int.). ${ }^{13}$ Hence resistance among the 
citizens arose and fewer and fewer were willing to contribute to the yan banga; residents instead organised fada on their doorsteps, regrouping youth they trusted, as an alternative to the vigilantes; the yan banga lost the support of both the chefs de quartier and the police; as a result, in Poudrière they have no longer existed in recent years.

In Kirkissoye, a peripheral neighbourhood on the right bank of the Niger River, three influential members of the community organised some youths to patrol the streets of their quarter at night. The chef de quartier was not part of this organisational committee, nor were the police informed. Yet they did not encounter resistance: the residents, including even high-ranking police officials, were willing to contribute either money or tea, sugar, rice and beans, kola nuts, in short, what the yan banga needed to make it through the night.

In Recasement, a peripheral quarter in the north-east of the Plateau, the formation of a yan banga group in the late 1990 os was of grass-roots character. Les enfants du quartier (the children of the neighbourhood) decided to take security into their own hands, as Boubacar Souleyman, an ex-yan banga, told me (2009 int.). In the beginning, a group of youths gathered every evening, first to play football, then to chat, drink tea and play cards in their fada until late at night. The host of the fada (Hausa: sarkin fada), in front of whose house the youth gathered every night, put up a list of participants which he presented to the police. Here they were rather informally recognised by the police and, unlike the yan banga in other neighbourhoods such as Poudrière, were not furnished with professional cards. From 10 p.m. onwards one group patrolled the streets of their neighbourhood while others were sitting at their base, their fada, preparing tea and food. Boubacar explained their operating mode:

If we see, for example, somebody we don't know in the neighbourhood, we will ask him to present his papers or to present himself. We take his identity card, verify name, first name, name of his residential quarter. We will ask him, 'What are you doing this late in the neighbourhood?' and he will give his explanations. If we don't trust him, he will follow us. We then take him to our fada and he will stay there. Without bothering us, without demonstrating his force. Because he is alone against us five, even if he is strong, he must follow us. We leave him in the fada until five, five thirty in the morning. Then we let him go. Because at that time, everybody is awake and if you want to steal something, now you cannot. If they are many, we will take them to the police station. There, they can give their explanations ... Because we are here to ensure security in our neighbourhood. Whatever you want to do, you will not do it in our corridor.

(Boubacar Souleyman 2009 int.) 
After the explosion of a landmine in Yantala, a pericentral quarter of Niamey where many military facilities are located, in January 2008, state officials urged the chefs de quartier to reinstate yan banga vigilante groups, albeit unsuccessfully. ${ }^{14}$ Following this incident, the governor of the urban municipality of Niamey assembled all chefs de quartier. He called upon them to recreate the yan banga in order to support the police in their mission to maintain public order - he explicitly asked for a 'rescue configuration' for the delivery of security, following Olivier de Sardan's terminology (201 1: 39). The chefs de quartier responded that if they were to organise a police de quartier (neighbourhood police) (Chef de quartier Poudrière 2008 int.), they would need the governor's financial support. The governor did not respond to the chiefs' demands, so the yan banga were not reformed under his supervision.

\section{Informal social control in the old town quarters}

Finally, there are neighbourhoods where there are neither private security agents nor police or yan banga patrols at night. These neighbourhoods are essentially the old town quarters in central Niamey, close to the three major markets and distinguished by the highest population densities. Buildings are essentially mud compounds and only the main streets are tarred. During the day, these streets are busy, due to the inhabitants predominantly pursuing commercial activities. After sunset the image of the streets is dominated by fada, circles of young people sitting in the streets. To highlight the fada's importance in the security landscape of Niamey, I will narrate one episode I experienced myself.

I had an appointment with the chef de quartier of Lacouroussou, one of Niamey's popular and oldest quarters, at 8:30 p.m. on a Wednesday evening. Since I arrived a little early, by 8:10, I decided to take a little walk in the neighbourhood. The sun had already set, and lamps, lanterns and TV sets lit some parts of the street, mostly in front of small huts sheltering grocery stores or snack bars. As I passed by the first fada, somebody greeted me in a way that was not too friendly, but not too harsh either; I responded without slackening my pace. The scenario was repeated when I passed by the second fada. After I had turned around the first corner, I was addressed by a young man sitting in the next fada. He greeted me in a friendly way and asked where I was heading. I explained that I had an appointment with the chief and, since I didn't stop here either, he let me continue my walk. From the next four or five fad $a$ which I passed there was always at least one young man who greeted me. After a few minutes - I was about to pass by another fada-a young man got up from his bench, welcomed me in his neighbourhood and asked me where I was from and where I was heading. 
I told him about my appointment with the chef de quartier and he instantly took me by the arm and lead me toward the chief's compound, very friendly though, demonstrating his interest in me by incessantly asking questions about where I was from, my job, etc. When we arrived at the chief's place, he placed me on a bench and entered the compound briefly. After a few seconds, he came out again and told me to wait for the chief to get ready. He wished me all the best for my endeavours and left for where we had come from.

Later in the evening, the chef de quartier proudly explained that his neighbourhood was, apart from casual brawls among the youth, one of the safest places in Niamey, even though there were no police patrols at all:

I have been chef de quartier for thirteen years and there has not been a single case of burglary, only petty theft within families. You know why? There are always people in the street, the whole night long. And everybody knows everybody. If you come and you are not from here, everybody will know it. And if you have no business being here, you need to explain what you want. If you are a thief, the youth will beat you well. They can even beat you to death! They are very proud and they can be so fierce! If you are a thief, you will run into the arms of the police rather than be caught by our youth.

(Chef de quartier Lacouroussou 2008 int.)

He probably embellished the facts a little, but his explanation helped me understand what had happened during my walk. I was recognised as a stranger the very moment I entered the neighbourhood from the tarred street. Not only was I recognised, they made me notice that I was recognised (unlike in other quarters where nobody seemed to care about me having a walk), and made sure I was not getting lost. From what many interlocutors told me, I got the impression that if I had not been white, the $f a d a$ 's reactions would probably have been somewhat harsher.

The fada I spent a lot of time with was on my neighbour's doorstep in Dar es Salaam, a rather peripheral neighbourhood. As a rule, every known person who passed by the fada was greeted. Girls were often called to stay for a chat; children were often sent to buy sugar or tea; adult women and men were greeted with due respect; only well-known 'madmen' ( fous) of the neighbourhood were ignored. Strangers usually greeted us first, giving us a silent but respectful Salamu Alaykum when passing by us, sometimes approaching us very politely, asking their way or just wishing us a good night - then they were offered a glass of tea. Unknown amblers who didn't greet us were suspect, my twenty-year-old 
neighbour and host of the fada told me. Usually one of the fada would address him rather bluntly: 'Hey buddy, where are you going? Don't you greet us?'15 This didn't happen often. And when it did, the unknown would approach us, apologise, and then be offered a glass of tea.

In Lacouroussou there were neither police nor organised vigilantes, and yet I felt like I was an object of efficient mechanisms of social control; in Dar es Salaam I was a member of a group who exercised this control. This is the most fundamental way of everyday policing by the public; it is 'one of the ways in which to create a separation between the "good" community and the evil outsiders' (Jensen 2007: 65).

\section{S T A T E, S E C U R I T Y, S O C I A L I T Y}

There has been much discussion in the social and political sciences about the role of the state in the provision of public goods in general and security in particular. A recurrent issue is the state-failure thesis, according to which alternative policing actors fill a security gap created by dysfunctional or absent state police organisations (Baker 2002: 30, 2006: 56; Harnischfeger 2003: 24; Lock 1998: 143; Pérouse de Montclos 2008: 20). On pragmatic grounds this may be persuasive, but it disregards the complex relations between state and alternative modes of policing. I agree with authors who suggest that instead of labelling these processes in negative terms as a retreat, failure or disruption of the state, social scientists should rather conceptualise it as a profound reconception and reconfiguration of the nature of the state (Bayart 2010b: 8; Comaroff \& Comaroff 2008: 21 6; Hibou 1999: 6; Singh 2008: 14), or at least counterpoint and complement the police-failure thesis with thick empirical research (Pratten 2007: 178). An intriguing analysis is presented by Olivier de Sardan (2011:32), who argues that the delivery of public goods such as security is (and has probably always been) the result of complex configurations involving multiple state and non-state actors and institutions.

As demonstrated above, in Niger neither private security enterprises nor the yan banga are beyond state control. This has been repeatedly demonstrated in the social science literature: non-state modes of policing such as these practiced by vigilante organisations or private security enterprises are often tightly intertwined with ideas and structures of the state. Buur (2006: 750) for example shows how vigilante organisations in South Africa draw on the state's procedural 
and symbolic forms; Ruteere and Pommerolle (2003: 603) argue that it is often close to impossible to draw a clear line between state policing and vigilantism in South Africa and Kenya; Harnischfeger (2003: 39) and Meagher (2007: 100) highlight the possibility of vigilante organisations being hijacked by state authorities in Nigeria (see also Adamu 2008), as did Lund (2001: 861) with regard to the yan banga in Zinder; Fleischer (2000) and Kyed (2007) show how the state outsourced policing by domesticating non-state vigilantes and thus turning them into state vigilantes in Tanzania and Mozambique; Dupont (2006: 181), as well as Shearing and Stenning (1983: 502-3), state that even in Western countries the production of security is dependent on a complex functioning of networks embracing state and non-state security agencies. In short, it has fortunately become common in social science to take into account the 'twilight character' (Lund 2006: 673) of policing organisations.

It is common to all accounts stated above that they focus on more or less formally organised groups exercising police functions such as state police, private security firms and vigilante groups. With the exception of mob justice (e.g. Baker 2005: 35-6, 2006: 69-71), little attention has been devoted to informal policing by the public as described by Shapland and Vagg (1988) and Jensen (2007). The focus on organised policing implies the misguided assumption that organisations produce security of a more stable and reliable kind than unorganised citizens do (Shapland \& Vagg 1988: 133). It therefore disregards what, for example, the fada do.

If we focus on the actual functioning of different modes of creating order in public space by both organised and non-organised groups of actors, we gain some insight into what security on a local scale is all about (Goldstein 2010: 488). As Pratten (2006: 711 ) argues, security, or more precisely the construction of order, is first and foremost about the definition of boundaries and the "protection and care of the community encompassed within these boundaries, and it involves maintaining surveillance and taking action against threats to this community' - it is about sociality (Pratten 2008: 11).

Police, private security agents, yan banga and fada are all engaged in a practice of filtering out (see Khayat 2002: 288) what they perceive as a potential threat to the neighbourhood they protect - to their community. Police make sure that poor city dwellers don't linger in Niamey's rich neighbourhoods; both yan banga and fada control access and circulation in their respective neighbourhoods. The police, mostly not working in their own residential area, have rather pragmatic aims, 
namely to obtain some extra money from those they intercept. ${ }^{16}$ The yan banga mostly have a clear sense of community because they police their own neighbourhood; they are the children of the community. And yet, there is a clear boundary between yan banga-as an organised group with fixed lists of participants and professional cards, which demands contributions from the neighbourhood dwellers - and other members of the community. A boundary always carries with it room for conflict. The community may change because of members moving away and richer people moving in, as in Recasement when it lost its peripheral character; the expectations of yan banga may differ from the expectations of the community up to the point where the yan banga distance themselves from the community in such a way that they themselves become thieves and burglars as in Poudrière.

The $f a d a$ 's case is fundamentally different. The fada I got to know in Lacouroussou and Dar es Salaam were neither organised nor regarded as an organisation. There are no lists of attendance; membership is floating; there are no artefacts designating membership; no fees are paid by residents. There is no formal boundary between the fad $a$ and the community; the fada are the community. And as actors being constantly present in public space they are intimately involved in the definition of social order in their neighbourhood (Shapland \& Vagg 1987: 61). Apart from the degree of organisation, one major difference between police, yan banga and fada is the extent to which they are rooted in the community they protect. It is thus not surprising that the fada are often described as an extremely efficient means of maintaining order: it becomes apparent that security is inseparable from sociality.

This seems to be true not only from the perspective of those engaged in policing, but also from the perspective of those subject to policing. Sometimes I and Ibrahim, a seventeen-year-old youth, took one-hour walks through Niamey. We would leave the compound of LASDEL (Laboratoire d'Etudes et de Recherches sur les Dynamiques Socials et le Développement Local), the research establishment where I had an office and where his father was employed as a night watchman. It was too late for me to catch a taxi, so I was heading home; Ibrahim was going to visit friends in my neighbourhood. I was amazed by his reluctance to take the tarred road which led almost straight to where we were heading. He preferred to zigzag the narrow and sandy paths right through residential areas (which I found much more exhausting because of the sand). His argument was this: we would only have to cross two large avenues, which meant that we limited the risk of confronting police patrols. A friend of 
his had already been caught once and since he didn't carry papers with him, he had to spend the night at the police station - an experience he was not keen on repeating. On our route through residential areas, Ibrahim greeted almost all the fad $a$ alongside our path. Some responded and wished us a good walk, some invited us to sit and have a glass of tea with them. Probably that is why this thirty-minute path turned into a onehour walk. Half of the time Ibrahim was concerned with socialising. When I asked him how he knew all those guys sitting in the streets, he responded that he had been walking this route for more than two years, ever since he had been visiting his friends in the quarter where I lived.

For Ibrahim, security is clearly about sociality - a 'balance of trust and acceptable risk' (Ericson 1994: 170). Ibrahim is more than merely traversing a given terrain; rather, he is responding to constellations which he cannot manipulate-like the police patrols on the main streets - and creating a terrain of familiarity, by always taking the same route and socialising with the youth and the watchmen on his path. Thereby, if we follow Niklas Luhmann's (2001) terminology, Ibrahim lays the groundwork for confidence (Zuversicht) and trust (Vertrauen), two basic modes of self-assurance, which are pre-conditions for dealing with dangers and risks. By composing a landscape of familiarity, and thus of sociality, he reduces the danger of being caught by the police or being attacked by villains in an unfamiliar and anonymous environment, and thus translates danger into an acceptable risk. Ibrahim is aware of the inseparability of security and sociality and thus creatively keeps trust and acceptable risk balanced.

\section{CONCLUSION：AN ACT OF TERRORISM IN NIAMEY}

For a comprehensive analysis of security, we must first decentre our perspective on security construction and thus take non-state modes of policing just as seriously as policing by state police organisations. Second, we must recognise the importance of non-organised modes of policing, like those represented by the fada. State or non-state, organised or non-organised, these institutions, groups and actors should be explored as equal parts in a complex field of security delivery. One way to do so is, I suggest, to acknowledge the inseparability of security and sociality, the fragile balance of trust and acceptable risk.

This is also a way of comprehending acts of terrorism such as the abduction of the two Frenchmen in Niamey. How was the abduction possible? Niamey's security landscape is a complex field consisting of multiple forms of state and non-state everyday policing. Each form of 
policing targets a specific form of crime or transgression, such as intrusion into one's community in the case of the yan banga and fada, and intrusion into the private property guarded by a watchman. They are not concerned with the form of transgression which occurred in Le Toulousain, the restaurant where the two Frenchmen were kidnapped. The ones who should be, namely state police, were ostensibly unable to effectively target and prevent this transgression. One obvious reason may be the lack of rigour at the police control barrier at the outskirts of Niamey, another the lack of communicative efficiency, as was highlighted by gendarmes whom I talked to after the abduction. These are valid points. Focusing on Niamey's security landscape reveals a much more trivial, yet equally valid, point: the kidnappers were driving white off-road vehicles, a type of car usually used by NGO employees or diplomatic personnel and thus permanently visible in the Plateau. This is why they did not raise the suspicion of state security agents and were consequently not filtered out. The kidnappers, through their appearance, blended into the security landscape. Furthermore, even if alternative policing actors like watchmen and fada, who are much more numerous and closer to the ground than the police, were noticing that an abduction was about to happen, state police organisations could not count on their vigilance and support - simply because "there is no global framework overarching the various forms of local co-delivery, no higher instance of coordination' (Olivier de Sardan 2011: 38 ).

The implications of this kidnapping were twofold. For Western expatriates it was a complete shock. 'Rien ne sera plus comme avant [Nothing will be as it was before]', wrote the online edition of the French newspaper Le Monde (12.1.2011), citing French expatriates in Niamey. They felt that the abduction 'marked a turning point in the mind, something collapsed ... Today, it can happen again because it has just happened once.' France withdrew the vast majority of its development workers from Niger; expatriates from other nationalities were urged not to walk or circulate in public spaces (also in the Plateau) after 8 p.m. and were asked to be at their residence by 10 p.m. at the latest, employees of the German Development Service told me. Nigérien city dwellers experienced different consequences. Since the abduction of the two Frenchmen, state police patrols have been significantly reinforced in the Plateau and other parts of Niamey, and thus so has the risk of being caught by police. For both expatriates and Nigeriéns, the perception of Niamey's security topography, and thus their circulation habits, have considerably changed. The balance of trust and acceptable risk was fundamentally shaken. 
Now what constitutes the act of terrorism? If we agree with Baudrillard, the act of terrorism is always one of symbolic violence (2002: 29-30), one that goes beyond the aims and intentions of the terrorists themselves (Butler 2010: 214). It is where myth and reality intertwine (Sluka 2002: 23) in a 'dynamics of form and formlessness' (Zulaika \& Douglass 1996: 150). On the surface, the kidnappers physically abducted two Frenchmen in order to put pressure on France to withdraw from Afghanistan. Beyond that, they brought mythical places of evil right into the supposedly best-secured diplomatic neighbourhood. They fundamentally shook Niamey's security topography. The landscape has partially lost its form. This, not the abduction as such, was a true act of terrorism. Whether this is only a temporary trembling of Niamey's security topography or has left a permanent imprint on it needs to be subject of further scrutiny.

\section{NOT E S}

1. The analyses presented in this article are drawn from a period of fifteen months of fieldwork in the Republic of Niger. I had informal conversations and interviews with watchmen (some of whom were ex-policemen), heads and office personnel of security companies, chefs de quartier (neighbourhood chiefs) who played an important role in the organisation of private night patrols in their respective neighbourhoods, and former members of vigilante groups called yan banga.

2. I do not refer to statistical evidence attesting an objective rise in crime rates (which are in Niger either non-existent or not reliable); I rather refer to subjective perceptions of my interlocutors.

3. The Samariya were part and parcel of Kountché's programme société de développement (society for development), with as main objective the mobilisation of the Nigérien population in non-political associations closely connected to the single party. For further details on the société de développement and the Samariya see Idrissa 2008: $169 \mathrm{ff}$.; Maignan 2000: 43 ff.; Mignon 1989.

4. These informal conversation groups (see also Youngsted 2004) can be described as one of the most important channels of radio trottoir as described by Ellis $(1989 ; 1993)$.

5. The degree to which fada are formally organised varies enormously. Some give themselves a name, have fixed membership, and establish membership lists. Whereas most fada have no particular objectives beyond being a place of amusement and informal communication, some can be described as neighbourhood NGOs (Le Sahel 6.6.2003), some as violent gangs (Le Damagaram May/June 2011 ).

6. In March 2003, thirty-two Europeans were abducted by the Algerien Salafist Group for Preaching and Combat GSPC (see Keenan 20ogb: 54 ff.), renamed al-Qaeda of the Islamic Maghreb in 2007 (Keenan 2009a: 14). Since then the US military presence in the Sahara has augmented significantly (Ellis 2004: 461) and some observers suggested 'that US policy towards the Sahara may have had the perverse effect of stimulating militant activity' (Ellis 2007: 22). Intriguing insights regarding this self-fulfilling prophecy were presented by the anthropologist Jeremy Keenan (2004: 694; 2006a: 9; 2007; 2009a; 2009b). From 2008 onwards the frequency of kidnappings in Niger increased rapidly: December 2008 (two Canadian diplomats kidnapped near Niamey; released); January 2009 (four European tourists kidnapped near the Mali-Niger border; three released, one executed); September 2010 (seven foreigners kidnapped in Arlit, in Niger's uranium mining zone; three released, four French still kept hostage); January 2011 (two French kidnapped in Niamey; killed during hostage rescue attempt).

7. Members of the PSI were Chad, Mali, Mauritania, Niger, Nigeria and Senegal; TSCTP added Algeria, Morocco and Tunisia.

8. I stress that empirical reality never fully matches these ideal-type spaces (see Weber 2002: 4). Their boundaries are floating, emphasis shifts from one mode of producing order to another, and they are contested by individuals navigating through and reappropriating them. 
9. It is thus no coincidence that most vigilante groups seem to have been created in such public spaces, mostly markets (see Baker 2006: 72; Fourchard 2003: 18; Harnischfeger 2003: 23; Lund 2001: 859-6o; Meagher 2007: 96-7).

10. The sector north and north-east of Boulevard Mali Béro is patrolled by the Garde Nationale, the sector on the right bank of the Niger river (in the city's south-west) by the Gendarmerie Nationale, and that between the river and Boulevard Mali Béro by the Police Nationale.

11. If not explicitly specified, I use the term police to denominate police, gendarmes and national guards alike.

12. I use the term vigilante in its broad sense as delineated by Abrahams (2007: 423): 'an organized attempt by a group of "ordinary citizens" to enforce norms and maintain law and order on behalf of their communities, often by resort to violence, in the perceived absence of effective official state action through the police and courts'.

13. The turning bad of vigilantes is intriguingly described by Rodgers (2007); Abrahams (1987: 180) notes that 'the boundary between vigilante and criminal, like that between heroes and bandits or patriots and traitors, is both fluid and manipulable'.

14. The landmine was supposedly planted there by members of Tuareg rebel groups. For an analysis of the Tuareg rebellion see Deycard 2007.

15. Hausa: 'Abokina, ina zaka? Ba ka gaida mu?'

16. For more nuanced ethnographic analysis of police officers' motivations in West Africa see Beek 2010.

\section{R E F E R E N C E S}

Abrahams, R. 1987. 'Sungusungu: village vigilante groups in Tanzania', African Affairs 86, 343: $179-96$.

Abrahams, R. 2007. 'Some thoughts on the comparative study of vigilantism', in Pratten \& Sen, eds. Global Vigilantes, $4^{1} 9-4^{2}$.

Adamu, F. L. 2008. 'Gender, hisba and the enforcement of morality in northern Nigeria', Africa 78, 1: $13^{6-52 .}$

Baker, B. 2002. 'Living with non-state policing in South Africa: the issues and dilemmas', Journal of Modern African Studies 40, 1: 29-53.

Baker, B. 2005. 'Multi-choice policing in Uganda', Policing and Society 15, 1: 19-41.

Baker, B. 2006. 'Beyond the state police in urban Uganda and Sierra Leone', Afrika Spectrum 41, 1: $55^{-76 .}$

Baudrillard, J. 2002. The Spirit of Terrorism and Other Essays. London: Verso.

Bayart, J.-F. 2010a. 'Le piège de la lutte antiterroriste en Afrique de l'Ouest', Sociétés politiques comparées 26, available at: www.fasopo.org/reasopo/n26/chronique.pdf, accessed 4.6.2011.

Bayart, J.-F. 2010b. 'Quelle politique africaine pour la France?', Sociétés politiques comparées 27, available at: www.fasopo.org/reasopo/n27/chronique.pdf, accessed 4.6.2011.

Beek, J. 2010. 'Étiqueter les “déviants”: le travail des policiers au Nord-Ghana', Déviance et Société 34, 2: 279-9o.

Bierschenk, T. 2008. 'The everyday functioning of an African public service: informalization, privatization and corruption in Benin's legal system', Journal of Legal Pluralism 5: 101-39.

Butler, R. 2010. 'Terrorism', in R. G. Smith, ed. The Baudrillard Dictionary. Edinburgh: Edinburgh University Press, $213^{-16 .}$

Buur, L. 2006. 'Reordering society: vigilantism and expressions of sovereignty in Port Elizabeth's townships', Development and Change 37, 4: 735-57.

Casey, C. 2007. "'Policing” through violence: fear, vigilantism, and the politics of Islam in northern Nigeria', in Pratten \& Sen, eds. Global Vigilantes, 93-124.

Comaroff, J. \& J. Comaroff 2008. 'Popular justice in the new South Africa: policing the boundaries of freedom', in T. R. Tyler, ed. Legitimacy and Criminal Justice: international perspectives. New York: Russell Sage Foundation, $215^{-37}$.

Davis, J. 2007. 'Introduction: Africa's road to the war on terror', in J. Davis, ed. Africa and the War on Terrorism. Aldershot: Ashgate, 1-14.

Deycard, F. 2007. 'Le Niger entre deux feux: la nouvelle rébellion Touarègue face à Niamey', Politique Africaine 108: 127-44.

Dupont, B. 2006. 'Delivering security through networks: surveying the relational landscape of security managers in an urban setting', Crime, Law $\mathcal{E}$ ' Social Change $45: 165-84$.

\section{CAMBridge JDURNALS}


Ellis, S. 1989. 'Tuning in to pavement radio', African Affairs 88, 352: $3^{21-30 .}$

Ellis, S. 1993. 'Rumour and power in Togo', Africa 63, 4: 462-76.

Ellis, S. 2004. 'Briefing: the Pan-Sahel Initiative', African Affairs 103, 41 2: 459-64.

Ellis, S. 2007. 'The Sahara and the "war on terror": a response to Jeremy Keenan', Anthropology Today 23, 3: $21-2$.

Ericson, R. V. 1994. 'The division of expert knowledge in policing and security', The British Journal of Sociology 45, 2: 149-75.

Fleischer, M. L. 2000. "Sungusungu": state-sponsored village vigilante groups among the Kuria of Tanzania', Africa 7o, 2: 209-28.

Fourchard, L. 2003. 'Le contrôle de la rue en Afrique Occidentale Française et au Nigeria, fin 19 ème siècle - 196o', in L. Fourchard \& I. O. Albert, eds. Sécurité, Crime et Ségrégation dans les Villes d'Afrique de l'Ouest du XIXe siècle à nos jours. Paris: Karthala, 101-17.

Fourchard, L. 2006. 'Les territoires de la criminalité à Lagos et Ibadan depuis les années 1930', TiersMonde 47, $185: 95^{-111 .}$

Gazibo, M. 2005. 'Foreign aid and democratization: Benin and Niger compared', African Studies Review 48, 3: 67-87.

Gervais, M. 1995. 'Structural adjustment in Niger: implementations, effects \& determining political factors', Review of African Political Economy 22, 63: 27-42.

Gilliard, P. \& L. Pédenon. 1996. 'Rues de Niamey, espace et territoires de la mendicité', Politique Africaine 63: 51-6o.

Goldstein, D. M. 2010. 'Toward a critical anthropology of security', Current Anthropology 51, 4: $4^{8} 7^{-}-5^{17}$.

Graybeal, N. L. \& L. A. Picard. 1991. 'Internal capacity and overload in Guinea and Niger', Journal of Modern African Studies 29, 2: 275-3oo.

Harnischfeger, J. 2003. 'The Bakassi Boys: fighting crime in Nigeria', Journal of Modern African Studies 41, 1: 23-49.

Hibou, B. 1999. " "La décharge”, nouvel interventionnisme', Politique Africaine 73: 6-15.

Hills, A. 1996. 'Towards a critique of policing and national development in Africa', Journal of Modern African Studies 34, 2: 271-91.

Hills, A. 2009. Policing Post-Conflict Cities. London: Zed Books.

Idrissa, K. 2008. 'Les régimes militaires entre 1974 et 1999 au Niger', in K. Idrissa, ed. Armée et Politique au Niger. Dakar: CODESRIA, 165-206.

Jensen, S. 2007. 'Policing Nkomazi: crime, masculinity and generational conflicts', in Pratten \& Sen, eds. Global Vigilantes, 47-68.

Keenan, J. 2004. 'Political destabilisation \& "blowback" in the Sahel', Review of African Political Economy 31, 102: 691-98.

Keenan, J. 2006a. "Conspiracy theories and "terrorists": how the "war on terror" is placing new responsibilities on anthropology', Anthropology Today 22, 6: 4-9.

Keenan, J. 2006b. 'Security \& insecurity in North Africa', Review of African Political Economy 33, 108 : 269-96.

Keenan, J. 2007. "The banana theory of terrorism: alternative truths and the collapse of the "second" (Saharan) front in the war on terror', Journal of Contemporary African Studies 25, 1: $3^{1-58 .}$

Keenan, J. 20oga. 'Al-Qaeda terrorism in the Sahara? Edwin Dyer's murder and the role of intelligence agencies', Anthropology Today 25, 4: 14-18.

Keenan, J. 20ogb. The Dark Sahara: American's war on terror in Africa. London: Pluto Press.

Khayat, T. 2002. 'La rue, espace réservé: voituriers et vigiles dans les nouvelles zones de loisirs à Beyrouth', Géocarrefour 77, 3: 283-8.

Kyed, H. M. 2007. 'State vigilantism and political community on the margins in post-war Mozambique', in Pratten \& Sen, eds. Global Vigilantes, 393-415.

Last, M. 2008. 'The search for security in Muslim northern Nigeria', Africa $78,1: 4^{1-63}$.

LeMonde.fr. 2011 . Available at: www.lemonde.fr/afrique/article/201 1/01/1 1/a-niamey-rien-ne-seraplus-comme-avant_1463788_3212.html\#ens_id=1411819, accessed 12.1.2011.

Lock, $\mathrm{P}$ 1998. 'The withering military in sub-Saharan Africa: new roles for the private security industry?', Afrika Spectrum 33, 2: $135^{-55}$.

Luhmann, N. 2001. 'Vertrautheit, Zuversicht, Vertrauen: Probleme und Alternativen', in M. Hartmann \& C. Offe, eds. Vertrauen: die Grundlage des sozialen Zusammenhalts. Frankfurt/Main: Campus-Verlag, 143-6o.

Lund, C. 2001. 'Precarious democratization and local dynamics in Niger: micro-politics in Zinder', Development and Change 32, 5: $845^{-69}$.

\section{CAMbridge JDURALS}


Lund, C. 2006. 'Twilight institutions: an introduction', Development and Change 37, 4: 673-84.

Maignan, J.-C. 200o. La Difficile Démocratisation du Niger. Paris: CHEAM.

Meagher, K. 2007. 'Hijacking civil society: the inside story of the Bakassi Boys vigilante group of south-eastern Nigeria', Journal of Modern African Studies 45, 1: 89-115.

Mignon, J.-M. 1989. 'Les mouvements de jeunesse dans l'Afrique de l'Ouest francophone, de $195^{8}$ aux années 1970-1975', in H. Almeida-Topor \& O. Georg, eds. Le Mouvement Associatif des Jeunes en Afrique Noire Francophone au XXe Siècle. Paris: L'Harmattan, 107-28.

Motcho, K. H. 2004. 'Croissance urbaine et insécurité dans la ville de Niamey', Geographica Helvetica 59, 3: 199-207.

Olivier de Sardan, J.-P. 2011 . 'Local powers and the co-delivery of public goods in Niger', IDS Bulletin 42, 2: $32-42$.

Palmer, R. D. 2007. 'Political terrorism in West Africa', in J. Davis, ed. Africa and the War on Terrorism. Aldershot: Ashgate, 103-1 2.

Pérouse de Montclos, M.-A. 2008. États Faibles et Sécurité Privée en Afrique Noire: de l'ordre dans les coulisses de la périphérie mondiale. Paris: Harmattan.

Pratten, D. 2006. 'The politics of vigilance in southeastern Nigeria', Development and Change 37: $707-34$.

Pratten, D. 2007. 'Singing thieves: history and practice in Nigerian popular justice', in Pratten \& Sen, eds. Global Vigilantes, $175^{-205}$.

Pratten, D. 2008. 'Introduction: the politics of protection: perspectives on vigilantism in Nigeria', Africa $78,1: 1-15$.

Pratten, D. \& A. Sen, eds. 2007. Global Vigilantes. London: Hurst.

Reuters, 2011. Available at: http://af.reuters.com/article/nigerNews/idAFLDE7OC1R120110113, accessed 13.1.2011.

Rodgers, D. 2007. 'When vigilantes turn bad: gangs, violence, and social change in urban Nicaragua', in Pratten \& Sen, eds. Global Vigilantes, 349-70.

Ruteere, M. \& M.-E. Pommerolle. 2003. 'Democratizing security or decentralizing repression? The ambiguities of community policing in Kenya', African Affairs 102, 409: 587-604.

Shapland, J. \& J. Vagg. 1987. 'Using the police', British Journal of Criminology 27: 54-63.

Shapland, J. \& J. Vagg. 1988. Policing by the Public. London: Routledge.

Shearing, C. D. \& P. C. Stenning 1983. 'Private security: implications for social control', Social Problems 3०, 5: 493-5o6.

Singh, A.-M. 2008. Policing and Crime Control in Post-Apartheid South Africa. Aldershot: Ashgate.

Sluka, J. 2002. 'What anthropologists should know about the concept of terrorism: a response to David Price', Anthropology Today 18, 2: 22-3.

Tidjani Alou, M. 2001. 'La dynamique de l'État post colonial au Niger', in K. Idrissa, ed. Le Niger: état et démocratie. Paris: L'Harmattan, $85^{-126 .}$

Weber, M. 2002 [1921]. Wirtschaft und Gesellschaft. Tübingen: Mohr-Siebeck.

Ya'u, Y. Z. 200o. 'The youth, economic crisis and identity transformation: the case of the yandaba in Kano', in A Jega, ed. Identity Transformation and Identity Politics under Structural Adjustment in Nigeria. Stockholm: Elanders Gotab, 161-8o.

Youngsted, S. M. 2004. 'Creating modernities through conversation groups: the everyday worlds of Hausa migrants in Niamey, Niger', African Studies Review 47, 3: 91-118.

Zulaika, J. \& W. A. Douglass 1996. Terror and Taboo: the follies, fables, and faces of terrorism. New York: Routledge.

\section{Newspapers (published in Niamey)}

Le Damagaram, Le Flic, Le Sahel, Sahel Dimanche, tamtaminfo.

\section{Interviews}

Boubacar Gandah, founder and director general EPSIG (Établissement Privé de Sécurité Incendie et Gardiennage), private security enterprise, Niamey, 24.1 2.2008.

Boubacar Souleyman, former yan banga, during my fieldwork watchman, Niamey, 4.10.20o9.

Chef de quartier Lacouroussou, Niamey, 14.12.2008.

\section{CAMBridge JDURNALS}


Chef de quartier Poudrière, Niamey, 27.1 2.2008.

Gendarme A, EPSIG regional supervisor in the Zinder region, Zinder, 17.11.2009.

Gendarme B, native of Zinder, Gouré, 29.6.2010.

Issifi Alzouma, commercial director GED Services, Niamey, 19.1 1.2008.

Mohamed, private security agent, Niamey, 2.12.2008.

Sarah, private security agent, former soldier in the Nigérien army, Niamey, 8.1 1.20o8.

Tahirou Issaka, director general GED Services (Gardiennage Entretien Désinsectisation), Niamey, 6.11 .2008

\section{CAMbridge JULRALS}

